\title{
PELIMPAHAN KEWENANGAN BPK KEPADA PERWAKILAN BPK DALAM PEMERIKSAAN DI DAERAH
}

\author{
Dessy Dwi Astuti1, Nabitatus Sa'adah² \\ Program Studi Magister IImu Hukum \\ Fakultas Hukum Universitas Diponegoro \\ J alan Imam Bardjo, S.H. No. 1-3, Kampus Pleburan, Semarang 50241 \\ dessy_das@yahoo.com
}

\begin{abstract}
This scientific journal is about the delegation of authority of the Supreme Audit Board (Badan Pemeriksa Keuangan or BPK) to Representatives/Executors at the BPK Regional Representatives within the framework of audits on Regional Governments, which is inspired by a lawsuit against the BPK Regional Representative of Jambi's Audit Report on the Financial Statements of Jambi City Regional Government Number 20.C/LHP/XVIII.JMB/5/2016. The indication of the problem is the form of delegation of BPK authority to BPK Representatives in the context of carrying out the task of examining the management and accountability of state finances in the Regional Government, until the issuance of the BPK Audit Report (LHP), looking from the source of the authority. The authority possessed by BPK is an attributive authority from the 1945 Constitution. Referring to the implementation of duties and authorities of BPK, in the BPK environment there are transfers of authority that are delegated and mandated to the Representatives of BPK. BPK as a state institution in carrying out its duties and authorities is inseparable from the General Principles of Good Governance as regulated in Act Number 30 Year 2014 concerning Government Administration. However, it is necessary to understand the limit of the transfer of authority by delegation and mandate within the BPK environment. The conclusion indicates that in the implementation of examining the management and accountability of state finances by the BPK Regional Representatives to the Regional Government, until the signing and issuance of the BPK Audit Report (LHP), there are delegation and mandate of authority involved. The regulation of delegation of authority needs to be consistent with Act Number 30 Year 2014 to anticipate legal problems that may arise.
\end{abstract}

\section{Keywords: Authority Delegation; Audit Reports.}

\begin{abstract}
ABSTRAK
Jurnal ilmiah ini mengenai Pelimpahan Kewenangan Badan Pemeriksa Keuangan (BPK) kepada Pelaksana di Perwakilan BPK dalam kerangka Pemeriksaan pada Pemerintah Daerah, dengan berdasar pada gugatan terhadap LHP BPK Perwakilan Provinsi Jambi atas Laporan Keuangan Pemerintah Daerah Kota Jambi Nomor 20.C/LHP/XVIII.JMB/5/2016. Indikasi permasalahan yaitu bagaimana bentuk pelimpahan kewenangan BPK kepada Pelaksana BPK dalam rangka pelaksanaan tugas pemeriksaan pengelolaan dan tanggungjawab keuangan negara pada Pemerintah Daerah, hingga terbitnya Laporan Hasil Pemeriksaan (LHP) BPK, ditinjau dari sumber kewenangannya. Kewenangan yang dimiliki oleh BPK merupakan kewenangan atribusi dari UUD 1945. Mengacu pada pelaksanaan tugas dan kewenangan BPK tersebut, di lingkungan BPK terdapat pelimpahan kewenangan yang bersifat delegasi dan mandat kepada Pelaksana BPK. BPK sebagai lembaga
\end{abstract}

\footnotetext{
${ }_{1}$ Mahasiswa Program Studi Magister IImu Hukum Universitas Diponegoro
}

2 Dosen Program Studi Magister Ilmu Hukum Universitas Diponegoro 
negara dalam melaksanakan tugas dan kewenangannya, tidak terlepas dari Asas-Asas Umum Pemerintahan yang Baik sebagaimana diatur dalam Undang-Undang Nomor 30 Tahun 2014 tentang Administrasi Pemerintahan, namun demikian perlu diketahui batasan pelimpahan wewenang secara delegasi dan mandat yang berlaku di lingkungan BPK. Kesimpulan yang dapat diambil bahwa dalam pelaksanaan pemeriksaan atas pengelolaan dan tanggung jawab keuangan negara oleh BPK Perwakilan kepada Pemerintah Daerah, hingga penandatanganan dan penerbitan Laporan Hasil Pemeriksaan (LHP) BPK Perwakilan, terjadi pelimpahan kewenangan yang bersifat delegasi dan mandat. Adapun pengaturan pelimpahan kewenangan tersebut perlu diselaraskan dengan Undang-undang Nomor 30 Tahun 2014 guna mengantisipasi permasalahan hukum yang akan timbul.

\section{Kata Kunci: Pelimpahan Kewenangan BPK; LHP B PK}

\section{A. PENDAHULUAN}

Istilah "kewenangan" atau "wewenang" dalam peraturan perundang-undangan di Indonesia dapat ditemukan baik dalam konsep hukum publik maupun hukum privat. Menurut Abdul Rasyid Thalib bahwa "kewenangan yang dimiliki oleh organ (institusi) pemerintahan atau lembaga negara dalam melakukan perbuatan nyata (riil), mengadakan pengaturan, atau mengeluarkan keputusan selalu dilandasi kewenangan yang diperoleh dari konstitusi secara atribusi, ataupun delegasi, ataupun mandat." (Bashori, 2015)

Kewenangan memiliki kedudukan penting dalam kajian hukum administrasi, karena berkenaan dengan pertanggungjawaban hukum dalam penggunaan wewenang, sejalan dengan salah satu prinsip negara hukum bahwa "tidak ada kewenangan tanpa pertanggungjawaban". Artinya dalam setiap pemberian kewenangan kepada pejabat pemerintahan tertentu, tersirat pertanggungjawaban pejabat yang bersangkutan. (Rokhim, 2013) Pada dasarnya, wewenang merupakan pengertian yang berasal dari hukum organisasi pemerintahan, yang dapat dijelaskan sebagai keseluruhan aturan-aturan yang berkenaan dengan perolehan dan penggunaan wewenang pemerintahan oleh subyek hukum publik di dalam hubungan hukum publik.

Badan Pemeriksa Keuangan (BPK) terbentuk berdasarkan Pasal 23 ayat (5) UUD 1945, dan berdasar pada UUD NRI Tahun 1945, pengaturan mengenai BPK diatur tersendiri dalam Bab VIII A, pada Pasal 23E, 23F, dan 23G. UU Nomor 15 Tahun 2006 tentang BPK menentukan BPK sebagai satu lembaga negara yang bebas dan mandiri dalam memeriksa pengelolaan dan tanggung jawab keuangan negara, yang berkedudukan di Ibukota negara, dan memiliki perwakilan di setiap provinsi. Keanggotaan BPK terdiri dari 9 (Sembilan) orang anggota dengan susunan terdiri atas seorang Ketua merangkap anggota, seorang Wakil Ketua merangkap anggota, dan 7 (tujuh) orang anggota. Tugas BPK diatur dalam Pasal 6, Pasal 7, dan Pasal 8 UU Nomor 15 Tahun 2006. Kewenangan BPK dijabarkan dalam Pasal 9 ayat (1), Pasal 10, dan Pasal 11 UU Nomor 15 Tahun 2006. Salah satu hasil pelaksanaan tugas dan wewenang BPK adalah Laporan Hasil Pemeriksaan (LHP). Hasil Pemeriksaan adalah hasil akhir dari proses penilaian 
kebenaran, kepatuhan, kecermatan, kredibilitas, dan keandalan data/informasi mengenai pengelolaan dan tanggung jawab keuangan negara yang dilakukan secara independen, objektif, dan profesional berdasarkan Standar Pemeriksaan yang dituangkan dalam laporan hasil pemeriksaan sebagai keputusan BPK.

Merujuk pada ketentuan Pasal 1 Angka 7 UU Nomor 30 Tahun 2014 tentang administrasi Pemerintahan, terkait Keputusan Administrasi Pemerintahan/ Keputusan Tata Usaha Negara/Keputusan Administrasi Negara, terdapat permasalahan yang muncul mengenai pelimpahan kewenangan di lingkungan BPK dan permasalahan mengenai LHP BPK apakah termasuk sebagai keputusan administrasi.

Salah satunya adalah gugatan atas LHP BPK. Gugatan ditujukan kepada Kepala BPK Perwakilan Provinsi Jambi. Obyek gugatan adalah LHP Nomor 20.C/LHP/XVIII.JMB/5/2016 tertanggal 30 Mei 2016. Terkait kewenangan, Majelis Hakim dalam Putusan Sela PTUN Kota Jambi nomor 20/G/2016/PTUN.JBI tanggal 13 Oktober 2016, menyatakan bahwa Tergugat mengeluarkan objek sengketa tidak dalam posisi penerima mandat, karena Surat Keputusan TUN Nomor 20.C/LHP/ XVIII.JMB/5/2016 tanggal 30 Mei 2016 tersebut tanpa menyebutkan atas nama BPK atau tidak menyebutkan atas nama Anggota $V$ BPK melalui Tortama KN V.

Berbeda dengan putusan sela, Majelis Hakim PTUN Jambi dalam Putusan Nomor 20/G/2016/PTUN.JBI tanggal 14 Februari 2016 berpendapat bahwa sumber kewenangan yang dimiliki oleh Tergugat selaku pelaksana tugas pemeriksaan BPK yang berkedudukan di Ibukota negara merupakan kewenangan yang sifatnya mandat sebagaimana maksud ketentuan Pasal 1 angka 3 UU Nomor 15 Tahun 2004 juncto Pasal 1 angka 10 UU Nomor 15 Tahun 2006. Putusan Majelis Hakim PTUN Kota Jambi menyatakan bahwa Surat Keputusan TUN Nomor 20.C/LHP/XVIII.JMB/5/2016 tertanggal 30 Mei 2016 yang dikeluarkan Tergugat tidak sah, dan mewajibkan Tergugat mencabut Surat Keputusan TUN Nomor 20.C/LHP/XVIII.JMB/ 5/2016. Putusan tersebut dikuatkan oleh Putusan PT TUN Nomor 85/B/2017/PT. TUN-MDN tanggal 23 Mei 2017. Namun Mahkamah Agung dalam Putusan Kasasi Nomor 446 K/TUN/2017 tanggal 30 Oktober 2017 membatalkan Putusan PT TUN Medan Nomor 85/B/2017/PT.TUN.MDN, tanggal 23 Mei 2017 yang menguatkan Putusan PTUN Jambi Nomor 20/G/2016/PTUN.JBI tanggal 14 Februari 2017.

Gugatan terhadap LHP BPK tersebut, mencerminkan ketidak sepemahaman antara BPK dengan pihak di luar BPK dalam memaknai pelimpahan wewenang yang terjadi di lingkungan BPK khususnya kewenangan BPK Perwakilan dalam melaksanakan tugas pemeriksaan atas pengelolaan dan tanggungjawab keuangan negara pada pemerintah daerah, dan dalam memandang LHP sebagai produk atas pelaksanaan tugas dan kewenangan BPK. 
Melalui pendekatan kajian yuridis normatif, penulisan ini mengurai mengenai kewenangan yang terjadi di lingkungan BPK kepada Perwakilan BPK.

\section{B. PEMBAHASAN}

\section{Pelimpahan Kewenangan}

Menurut Philipus M. Hadjon, tiga komponen dasar hukum administrasi meliputi: a) Hukum untuk penyelenggaraan pemerintahan yang meliputi sumber wewenang (atribusi, delegasi, dan mandat), asas penyelenggaraan pemerintahan (asas negara hukum, asas legalitas), diskresi, dan prosedur penggunaan wewenang; b) Hukum oleh pemerintahan yaitu instrument hukum yang digunakan oleh pemerintah; dan c) Hukum terhadap pemerintahan yaitu berkaitan dengan perlindungan hukum bagi rakyat terhadap tindak pemerintah. (Hadjon, 2010). H.D. van Wijk/Willem Konijnenbelt (1995) yang dikutip oleh DR. Ridwan HR mendefinisikan atribusi, delegasi, dan mandat sebagai berikut a) Atribusi adalah pemberian wewenang pemerintahan oleh pembuat undangundang kepada organ pemerintahan; b) Delegasi adalah pelimpahan wewenang pemerintahan dari satu organ pemerintahan kepada organ pemerintahan lainnya; c) Mandat terjadi ketika organ pemerintahan mengizinkan kewenangannya dijalankan oleh organ lain atas namanya. (HR, 2017)

Indroharto (1993) sebagaimana dikutip DR. Ridwan HR mengatakan bahwa Pada atribusi terjadi pemberian wewenang pemerintahan yang baru oleh suatu ketentuan dalam peraturan perundangundangan. Di sini dilahirkan atau diciptakan suatu wewenang baru. Pada delegasi terjadilah pelimpahan suatu wewenang yang telah ada oleh Badan atau Jabatan Tata Usaha Negara yang telah memperoleh wewenang pemerintahan secara atributif kepada Badan atau Jabatan Tata Usaha Negara lainnya. Sehingga suatu delegasi selalu didahului oleh adanya suatu atribusi wewenang. (HR, 2017)

Philipus M. Hadjon menyatakan bahwa Mandat merupakan pelimpahan wewenang yang terjadi dalam hubungan rutin atasan-bawahan. Dalam hal ini tidak diperlukan peraturan perundangundangan yang mendasarinya, kecuali dilarang secara tegas. Tanggung jawab dan tanggung gugat tetap berada pada pemberi mandat. Setiap saat pemberi mandat dapat menggunakan kembali wewenang yang telah dilimpahkan tersebut. Pada delegasi, pelimpahan wewenang terjadi dari suatu organ pemerintahan kepada organ lain. Untuk itu diperlukan peraturan perundang-undangan yang menjadi dasar pengaturannya. Tanggung jawab dan tanggung gugat beralih kepada penerima delegasi (delegataris). Pemberi delegasi tidak dapat menggunakan kembali wewenang yang dilimpahkan tersebut kecuali terdapat pencabutan delegasi. (Hadjon, 1997)

UU PTUN dan UU Administrasi Pemerintahan mengatur mengenai pelimpahan wewenang. Lingkup pengaturan dalam kedua undang-undang tersebut adalah pengaturan bagi pejabat pemerintahan. Pada kedua undang-undang tersebut menyebutkan siapa yang dimaksud dengan Pejabat TUN dan/atau Pejabat Pemerintahan, yaitu orang (pejabat/ unsur) 
yang melaksanakan urusan/ fungsi pemerintahan. Definisi fungsi pemerintahan, tercantum dalam Pasal 1 Angka 2 UU Administrasi Pemerintahan yaitu "Fungsi Pemerintahan adalah fungsi dalam melaksanakan Administrasi Pemerintahan yang meliputi fungsi pengaturan, pelayanan, pembangunan, pemberdayaan, dan pelindungan."

Berdasar UU Administrasi Pemerintahan, atribusi merupakan pemberian kewenangan kepada Badan dan/atau Pejabat Pemerintahan oleh UUD Negara RI Tahun 1945 atau Undang-Undang. Delegasi merupakan pelimpahan kewenangan dari Badan dan/atau Pejabat Pemerintahan yang lebih tinggi kepada Badan dan/atau Pejabat Pemerintahan yang lebih rendah dengan tanggung jawab dan tanggung gugat beralih sepenuhnya kepada penerima delegasi. Adapun mandat merupakan pelimpahan kewenangan dari Badan dan/atau Pejabat Pemerintahan yang lebih tinggi kepada Badan dan/atau Pejabat Pemerintahan yang lebih rendah dengan tanggung jawab dan tanggung gugat tetap berada pada pemberi mandat.

Badan dan/atau Pejabat Pemerintahan memperoleh wewenang melalui atribusi apabila diatur dalam UUD Negara Republik Indonesia Tahun 1945 dan/atau undang-undang, merupakan wewenang baru atau sebelumnya tidak ada, dan atribusi diberikan kepada Badan dan/atau pejabat Pemerintahan. Badan dan/atau Pejabat Pemerintahan yang memperoleh wewenang melalui atribusi, tanggung jawab kewenangan berada pada Badan dan/atau Pejabat Pemerintahan yang bersangkutan. Kewenangan atribusi tidak dapat didelegasikan, kecuali diatur di dalam UndangUndang Dasar Negara Republik Indonesia Tahun 1945 dan/atau undang-undang. (Muskamal, 2016)

Pelimpahan wewenang secara delegasi yang berlaku selama ini bahwa "pemberi delegasi tidak dapat menggunakan lagi wewenang yang sudah dilimpahkan, kecuali setelah ada pencabutan dengan berpegang pada asas contraries actus". Apabila sebuah Keputusan TUN terdapat kekeliruan administratif atau cacat yuridis, yang berhak mencabut suatu Keputusan TUN adalah pejabat/instansi yang mengeluarkan Keputusan TUN itu sendiri dan dilakukan dengan peraturan yang setaraf atau yang lebih tinggi.

Pasal 13 ayat (5) UU Administrasi Pemerintahan menentukan secara berbeda, bahwa Badan dan/atau Pejabat Pemerintahan yang memberikan Delegasi dapat menggunakan sendiri wewenang yang telah diberikan melalui Delegasi, kecuali ditentukan lain dalam ketentuan peraturan perundang-undangan. Namun demikian ditentukan pula dalam ayat selanjutnya bahwa penarikan pemberian wewenang secara delegasi tersebut dapat dilakukan manakala pelaksanaan wewenang berdasarkan delegasi menimbulkan ketidakefektifan penyelenggaraan pemerintahan.

Peraturan Menteri Pendayagunaan Aparatur Negara dan Reformasi Birokrasi Nomor 80 Tahun 2012 tentang Pedoman Tata Naskah Dinas Instansi Pemerintah, pada Bab V Pejabat Penanda Tangan Naskah Dinas mengatur antara lain: 
a. Penandatanganan surat dinas

1) Atas nama (a.n.)

Digunakan jika pejabat yang menandatangani surat dinas telah diberi kuasa oleh pejabat yang bertanggung jawab, berdasarkan bidang tugas dan tanggung jawab pejabat yang bersangkutan.

Atas nama merupakan jenis pelimpahan wewenang secara mandat dalam hubungan internal antara atasan kepada pejabat setingkat dibawahnya. Dipergunakan jika yang berwenang menandatangani surat/dokumen melimpahkan kepada pejabat di bawahnya. Ketentuan atas nama, yaitu pelimpahan wewenang dalam bentuk tertulis, materi wewenang yang dilimpahkan benar-benar menjadi tugas dan tanggung jawab pejabat yang melimpahkan, tanggung jawab akhir akibat pelimpahan wewenang tersebut berada pada pejabat yang melimpahkan wewenang, dan pejabat yang menerima pelimpahan wewenang harus memberikan pertanggungjawaban kepada pejabat yang melimpahkan wewenang. (Utomo, 2016)

2) Untuk Beliau (u.b.)

Digunakan jika yang diberikan kuasa memberikan kuasa lagi kepada pejabat satu tingkat di bawahnya, sehingga untuk beliau (u.b.) digunakan setelah atas nama (a.n.). Pelimpahan wewenang ini mengikuti urutan sampai dua tingkat struktural di bawahnya.

Untuk Beliau merupakan jenis pelimpahan wewenang secara mandat, dalam hubungan internal antara atasan kepada pejabat dua tingkat di bawahnya. Ketentuan atas Beliau bahwa pelimpahan harus mengikuti urutan hanya sampai dua tingkat struktural dibawahnya, materi yang ditangani merupakan tugas dan tanggung jawabnya, dapat dipergunakan oleh pejabat yang ditunjuk sebagai pejabat pengganti (PIt. atau Plh.), dan tanggung jawab akhir akibat pelimpahan wewenang tersebut berada pada pejabat yang melimpahkan wewenang. (Utomo, 2016)

b. Kewenangan Penandatanganan

1) Kewenangan untuk melaksanakan dan menandatangani surat dinas antar/keluar instansi pemerintah yang bersifat kebijakan/ keputusan/arahan berada pada pejabat pimpinan tertinggi instansi pemerintah.

2) Kewenangan untuk melaksanakan dan menandatangani surat yang tidak bersifat kebijakan/ keputusan/ arahan dapat diserahkan/ dilimpahkan kepada pimpinan organisasi di setiap tingkat eselon atau pejabat lain yang diberi kewenangan untuk menandatanganinya.

3) Penyerahan/pelimpahan wewenang dan penandatanganan korespondensi kepada pejabat kepala/pimpinan dilaksanakan sebagai berikut:

a) Sekretaris jenderal / sekretaris menteri / sekretaris utama lembaga pemerintah nonkementerian, pimpinan sekretariat lembaga negara, sekretaris daerah provinsi, sekretaris daerah kabupaten/kota, dan lembaga lainnya dapat memperoleh pelimpahan kewenangan dan penandatanganan surat dinas tentang 
supervisi, arahan mengenai rencana strategis dan operasional, termasuk kegiatan lain yang dilaksanakan oleh organisasi lini di instansi masing masing.

b) Pimpinan organisasi lini pada setiap jajaran instansi pemerintah dapat memperoleh penyerahan/pelimpahan wewenang dan penandatanganan surat dinas yang berkaitan dengan pelaksanaan tugas dan fungsi sesuai dengan bidang masing-masing.

\section{Pelimpahan Kewenangan BPK Kepada Pelaksana BPK di BPK Perwakilan}

UUD 1945 memberikan kewenangan atribusi kepada BPK untuk melakukan pemeriksaan pengelolaan dan tanggung jawab keuangan negara. UUD 1945 juga mengatur bahwa ketentuan mengenai keuangan negara dan BPK akan diatur lebih lanjut dalam Undang-Undang. Keuangan negara diatur dalam UU No 17 Tahun 2003 tentang Keuangan Negara. Keuangan Negara adalah semua hak dan kewajiban negara yang dapat dinilai dengan uang, serta segala sesuatu baik berupa uang maupun berupa barang yang dapat dijadikan milik negara berhubung dengan pelaksanaan hak dan kewajiban tersebut. Pengelolaan keuangan negara harus dilaksanakan secara tertib, dan salah satu upaya untuk mewujudkan transparansi dan akuntabilitas pengelolaan tersebut adalah adanya pemeriksaan keuangan oleh badan pemeriksa yang bebas dan mandiri untuk memeriksa pengelolaan dan pertanggungjawaban. Hal ini merupakan merupakan salah satu asas dalam pengelolaan keuangan negara. Pasal 33 UU No 17 Tahun 2003 mengatur bahwa pemeriksaan pengelolaan dan pertanggungjawaban keuangan negara diatur dalam UU, UU ini adalah UU No 15 Tahun 2004 tentang Pemeriksaan Pengelolaan dan Tanggung Jawab Keuangan Negara. (Anggoro, 2018)

BPK berkedudukan di Ibukota negara, dan memiliki perwakilan di setiap provinsi. Keanggotaan BPK yang diatur dalam UU Nomor 15 Tahun 2006 terdiri dari 9 (Sembilan) orang anggota, terdiri atas seorang Ketua merangkap anggota, seorang Wakil Ketua merangkap anggota, dan 7 (tujuh) orang anggota, dimana dalam menjalankan tugas dan wewenangnya, berdasarkan Pasal 34 UU Nomor 15 Tahun 2006 BPK dibantu oleh Pelaksana BPK, yang terdiri atas Sekretaris Jenderal, unit pelaksana tugas pemeriksaan (Auditorat), unit pelaksana tugas penunjang, perwakilan, Pemeriksa/Auditor, dan pejabat lain yang ditetapkan oleh BPK sesuai dengan kebutuhan. BPK Perwakilan yang berkedudukan di setiap provinsi dipimpin oleh seorang Kepala Perwakilan.

Hubungan kerja antara BPK Pusat dengan BPK Perwakilan terjadi dalam beberapa hal antara lain dalam Penyusunan Rencana Kerja Pemeriksaan yang dibahas dalam Rapat Kerja BPK, Penyampaian LHP yang telah dilakukan oleh BPK Perwakilan kepada BPK Pusat melalui Tortama dan Anggota yang membawahi BPK Perwakilan, Penyampaian hasil pemantauan tindak lanjut atas rekomendasi LHP BPK Perwakilan kepada BPK Pusat utuk dijadikan bahan penyusunan Ikhtisar Hasil 
Jurnal Pembangunan Hukum Indonesia

Volume 1, Nomor 1, Tahun 2019
Program Studi Magister Ilmu Hukum Fakultas Hukum Universitas Diponegoro
Pemeriksaan Semester yang selanjutnya akan disampaikan kepada DPR, DPRD, dan Pemerintah (Presiden, Gubernur, dan Bupati/Walikota), dan Rapat Kerja, Rapat Koordinasi, Rapat Koordinasi Teknis Pemeriksaan, dan Rapat Pemeriksaan Tematik. (Wiyaliyanti, Hananto, \& Juliani, 2016)

Pelimpahan wewenang yang bersifat delegatif dari BPK kepada Pejabat yang diberi penugasan secara tertulis oleh BPK untuk bertanggung jawab dalam hal pelaksanaan tugas pemeriksaan hingga penjaminan mutu atas LHP BPK. Pelimpahan wewenang yang bersifat mandat dari BPK kepada Pejabat yang diberi penugasan tertulis untuk bertanggung jawab terkait naskah kedinasan yang berhubungan dengan pelaksanaan pemeriksaan maupun penyampaian hasil pemeriksaan.

\section{Masalah Pelimpahan Kewenangan dalam Gugatan Terhadap LHP BPK}

Majelis Hakim pada Pengadilan TUN Jambi dan PT TUN Medan dalam memutuskan perkara Gugatan Nomor 20/G/2016/PTUN.JBI berpedoman pada UU Administrasi Pemerintahan, sehingga melihat LHP BPK sebagai Keputusan TUN yang merupakan perbuatan konkret dalam rangka penyelenggaraan pemerintahan, dan Kepala Perwakilan BPK Perwakilan Provinsi Jambi tepat didudukkan sebagai Tergugat karena sebagai Pejabat TUN yang mengeluarkan LHP BPK. Kepala Perwakilan BPK Perwakilan Provinsi Jambi dalam mengeluarkan LHP BPK adalah cacat secara yuridis karena tidak memenuhi syarat norma mengenai pelimpahan kewenangan yang bersifat mandat sebagaimana telah ditentukan secara implisit dalam peraturan perundang-undangan, sehingga merupakan keputusan yang tidak sah.

Ruang lingkup UU Administrasi Pemerintahan tidak tepat apabila digunakan sebagai dasar hukum di dalam pertimbangan Majelis Hakim untuk menilai keabsahan LHP BPK. Ruang lingkup UU Administrasi Pemerintahan mengatur mengenai Badan dan/atau Pejabat Pemerintahan yang melaksanakan fungsi pemerintahan dan bukan fungsi kewenangan kelembagaan atas amanat konstitusi seperti yang dijalankan oleh BPK dalam menerbitkan LHP BPK. UU Administrasi Pemerintahan menyebutkan bahwa "fungsi Pemerintahan adalah fungsi dalam melaksanakan Administrasi Pemerintahan yang meliputi fungsi pengaturan, pelayanan, pembangunan, pemberdayaan dan perlindungan." Selanjutnya disebutkan "Badan dan/atau Pejabat Pemerintahan adalah unsur yang melaksanakan Fungsi Pemerintahan, baik di lingkungan pemerintah maupun penyelenggara negara lainnya." Ketentuan tersebut sejalan dengan ketentuan UU PTUN yang menyebutkan:

a. Pasal 1 Angka 1 bahwa Tata Usaha Negara adalah administrasi negara yang melaksanakan fungsi untuk menyelenggarakan urusan pemerintahan baik di pusat maupun di daerah. Penjelasan Pasal 1 angka 1, bahwa yang dimaksud dengan "urusan pemerintahan" ialah kegiatan yang bersifat eksekutif.

b. Pasal 1 Angka 2 bahwa Badan atau Pejabat Tata Usaha Negara adalah badan atau pejabat yang 
melaksanakan urusan pemerintahan berdasarkan peraturan perundang-undangan yang berlaku. Penjelasan Pasal 1 angka 2, bahwa Badan atau Pejabat Tata Usaha Negara adalah Badan atau Pejabat di pusat dan daerah yang melakukan kegiatan yang bersifat eksekutif.

UUD NRI 1945 mendudukkan Pemerintah dan BPK secara sejajar. Kekuasaan pemerintahan negara yang dipegang pemerintah diatur dalam $B A B$ III tentang kekuasaan Presiden dan Wakil Presiden, dimana diantaranya diatur bahwa Presiden merupakan pemegang kekuasaan pemerintahan. BPK diatur dalam BAB VIIIA sebagai lembaga negara yang bertugas melaksanakan pemeriksaan terhadap pengelolaan dan pertanggungjawaban keuangan negara yang dilaksanakan oleh Pemerintah. Dari sumber kewenangan BPK tersebut, BPK berada di luar kekuasaan eksekutif (pemerintah), legislatif, dan yudikatif, berkedudukan sederajat dan bersifat independen. Hal demikian membuktikan bahwa BPK merupakan external auditor dalam bidang pemeriksaan pengelolaan dan tanggung jawab keuangan negara yang memiliki hubungan dengan kekuasaan legislatif dalam melakukan pengawasan tindakan pemerintahan. (Rosyadi, 2016)

Tugas dan kewenangan BPK yang secara atribusi diberikan oleh konstitusi UUD 1945 untuk melaksanakan pemeriksaan atas pengelolaan dan tanggung jawab keuangan negara, hingga menerbitkan LHP BPK, tidak dapat disamaartikan dengan melaksanakan administrasi pemerintahan yang meliputi fungsi pengaturan, pelayanan, pembangunan, pemberdayaan dan perlindungan sesuai yang tertuang dalam UU Administrasi Pemerintahan. Dalam melaksanakan tugas dan wewenang terkait fungsi pemeriksaan dimaksud, BPK tidak tunduk pada ketentuan dalam UU Administrasi Pemerintahan, namun bukan berarti BPK tidak tunduk samasekali terhadap UU Administrasi Pemerintahan, karena BPK tetap tunduk pada UU Administrasi Pemerintahan sebatas dalam menjalankan fungsi pemerintahannya.

Sekretariat Jenderal BPK yang dipimpin oleh Sekretaris Jenderal sebagai salah satu Pelaksana BPK membawahi seluruh Pelaksana BPK dengan fungsinya melaksanakan administrasi pemerintahan untuk menunjang kegiatan BPK dalam menjalankan kewenangan kelembagaannya melakukan pemeriksaan pengelolaan dan tanggung jawab keuangan negara. Fungsi pemerintahan tidak dilakukan oleh BPK, tetapi dilakukan oleh Sekretaris Jenderal, sebagai contoh adalah penerbitan Surat Keputusan Sekretaris Jenderal BPK terkait pemindahan jabatan pegawai, terkait Hukuman disiplin kepegawaian, dan Surat Keputusan Sekretaris Jenderal BPK lainnya.

SF. Marbun, dikutip HR. Ridwan, menyatakan bahwa kelompok Badan atau Pejabat TUN yang menyelenggarakan urusan, fungsi atau tugas pemerintahan, yakni a) Mereka yang termasuk dalam lingkungan eksekutif mulai dari Presiden sebagai Kepala Pemerintahan (termasuk pembantupembantunya di Pusat seperti Wakil Presiden, 
para menteri dan LPND); b) Mereka yang menyelenggarakan urusan desentralisasi; c) Mereka yang menyelenggarakan urusan dekonsentrasi; d) Pihak ketiga atau pihak swasta yang mempunyai hubungan istimewa atau hubungan biasa dengan pemerintah baik yang diatur atas dasar hukum publik maupun hukum privat; e) Pihak ketiga atau swasta yang memperoleh konsesi atau izin dari pemerintah; f) Pihak ketiga atau swasta yang diberi subsidi oleh pemerintah misalnya sekolah-sekolah swasta; g) Yayasan-yayasan yang didirikan dan diawasi oleh pemerintah; h) Pihak ketiga atau koperasi yang didirikan dan diawasi oleh pemerintah; i) Pihak-pihak atau Bank-bank yang didirikan dan diawasi oleh pemerintah; j) Pihak ketiga atau swasta yang bertindak bersama-sama dengan pemerintah (persero); k) Kepaniteraan pada Pengadilan Negeri, Tinggi dan Mahkamah (Agung); dan I) Sekretariat pada Lembaga Tinggi Negara (MPR) dan Lembagalembaga Tinggi Negara (DPR, MK, MA dan BPK) serta sekretariat pada DPRD. (HR, 2007)

BPK dalam menjalankan fungsi lembaganya sesuai amanat Pasal 23E UUD NRI 1945 dalam melaksanakan pemeriksaan pengelolaan dan tanggung jawab keuangan negara bukan dalam rangka menjalankan fungsi pemerintahan sehingga BPK tidak termasuk dalam subjek tata usaha negara. LHP BPK bukan merupakan objek yang dapat diuji di peradilan. Hal tersebut dikuatkan dalam Pasal 33 ayat (1) UU Nomor 15 tahun 2006 tentang BPK yang menyatakan bahwa "Untuk menjamin mutu pemeriksaan pengelolaan dan tanggung jawab keuangan negara oleh BPK sesuai dengan standar, sistem pengendalian mutu BPK ditelaah oleh badan pemeriksa keuangan negara lain yang menjadi anggota organisasi pemeriksaan keuangan sedunia." Fatwa Mahkamah Agung Nomor 19/KMA/HK.01/III/2014 tanggal 25 Maret 2014 point 3 sampai dengan 5 yang menyatakan bahwa Berdasarkan UU Nomor 15 Tahun 2004 dan UU Nomor 15 Tahun 2006, tidak ada lembaga/badan/entitas lain yang diberikan kewenangan untuk melakukan penilaian/pengujian terhadap Laporan Hasil Pemeriksaan BPK. Namun demikian, untuk menjamin mutu pemeriksaan pengelolaan dan tanggung jawab keuangan negara oleh BPK agar sesuai dengan standar, maka sistem pengendalian mutu BPK, hanya bisa dinilai/ditelaah/diuji oleh suatu lembaga yang secara profesi memiliki kompetensi di bidang pemeriksaan atas pengelolaan dan tanggung jawab keuangan negara, yaitu badan Pemeriksa (BPK) negara lain yang menjadi anggota organisasi pemeriksa keuangan negara se-dunia (Pasal 33 UU Nomor 15 Tahun 2006 tentang BPK). Berdasarkan alasanalasan tersebut, temuan/rekomendasi Hasil Pemeriksaan BPK adalah produk yang substansi kebenaran hasil pemeriksaannya bukan objek yang dapat diuji di peradilan.

Kepala Perwakilan merupakan pelaksana tugas pemeriksaan BPK yang memperoleh kewenangan secara mandat dari BPK RI yang berkedudukan di Ibukota Negara. LHP BPK merupakan hasil pemeriksaan yang dikeluarkan oleh 
Kepala Perwakilan BPK, namun tanggung jawab atas dikeluarkannya LHP tersebut tidak berada pada Kepala Perwakilan BPK. BPK Perwakilan Provinsi Jambi adalah salah satu unsur Pelaksana BPK yang berada di bawah AKN $\mathrm{V}$ dan bertanggung jawab kepada Anggota V. Pemeriksaan yang dilakukan oleh BPK Perwakilan hingga menerbitkan LHP merupakan pelaksanaan pelimpahan kewenangan secara mandat. Tanggung jawab dan tanggung gugat berada pada pemberi mandat yaitu BPK yang berkantor di Jakarta, sehingga yang bertanggung jawab terhadap LHP BPK adalah BPK sebagai suatu lembaga.

Mahkamah Agung berpendapat bahwa BPK dalam menjalankan fungsi lembaganya melaksanakan pemeriksaan pengelolaan dan tanggung jawab keuangan negara sebagaimana diatur dalam UUD 1945 bukan dalam rangka menjalankan fungsi pemerintahan, sehingga keputusannya bukan sebagai objek sengketa di Peradilan Tata Usaha Negara. Mahkamah Agung dalam Putusan Kasasi Nomor 446 K/TUN/2017 tanggal 30 Oktober 2017 membatalkan Putusan Pengadilan Tinggi Tata Usaha Negara Medan Nomor 85/B/2017/PT.TUN.MDN, tanggal 23 Mei 2017 yang menguatkan Putusan Pengadilan Tata Usaha Negara Jambi Nomor 20/G/2016/PTUN.JBI tanggal 14 Februari 2017.

\section{SIMPULAN}

Berdasarkan sumber kewenangan yang diperoleh BPK yang berasal dari UUD 1945 dan undang-undang, terdapat pelimpahan wewenang secara atributif kepada BPK sebagai lembaga negara yang memiliki tugas dan fungsi melaksanakan pemeriksaan atas pengelolaan dan tanggungjawab keuangan negara. Dalam pelaksanaan pemeriksaan atas pengelolaan dan tanggung jawab keuangan negara oleh BPK Perwakilan terhadap Pemerintah Daerah, hingga penandatanganan dan penerbitan Laporan Hasil Pemeriksaan (LHP) BPK Perwakilan, terjadi pelimpahan kewenangan yang bersifat delegasi dan mandat. LHP BPK yang diatur dalam UU Nomor 15 Tahun 2004 merupakan hasil akhir dari serangkaian proses pelaksanaan tugas dan fungsi pemeriksaan atas pengelolaan dan tanggung jawab keuangan negara yang dituangkan dalam Keputusan BPK, bukan merupakan produk dari Sekretariat Jenderal BPK, sehingga LHP BPK tidak memenuhi syarat sebagai Keputusan Tata Usaha Negara.

Berdasarkan gugatan atas LHP, dalam hal pelimpahan kewenangan, sebagaimana ketentuan Pasal 1 angka 3 UU Nomor 15 Tahun 2004 juncto Pasal 1 angka 10 UU Nomor 15 Tahun 2006 yang menyatakan bahwa "Pemeriksa adalah orang yang melaksanakan tugas pemeriksaan pengelolaan dan tanggung jawab keuangan negara untuk dan atas nama BPK", maka Kepala Perwakilan BPK Perwakilan Provinsi Jambi merupakan pelaksana tugas pemeriksaan BPK yang memperoleh kewenangan secara mandat dari BPK RI yang berkedudukan di Ibukota Negara. 
Jurnal Pembangunan Hukum Indonesia

Volume 1, Nomor 1, Tahun 2019
Program Studi Magister Ilmu Hukum Fakultas Hukum Universitas Diponegoro

\section{DAFTAR PUSTAKA}

\section{BUKU}

Bashori, Dhofir C. (2015). Kompetensi Mahkamah Konstitusi dalam Mengadili Sengketa Pemilukada Sebelum dan Sesudah berlakunya Undang-Undang Nomor 1 Tahun 2015 jo Undang-Undang Nomor 8 Tahun 2015 Tentang Pemilihan Gubernur, Bupati, dan Walikota (Doctoral dissertation, UIN Sunan Ampel Surabaya).

HR, Ridwan. (2017) Hukum Administrasi Negara.

Jakarta: Raja Grafindo Persada.

Hadjon, Philipus M. (2010) Kebutuhan Akan Hukum

Administrasi Umum, dalam Philipus M. Hadjon

et.al, Hukum Administrasi dan Good Governance, Jakarta: Penerbit Universitas Trisakti.

\section{JURNAL}

Anggoro, C. (2018). Kewenangan Pemeriksaan Badan Pemeriksa Keuangan atas Badan Usaha Milik Negara, Varia J usticia Universitas Muhammadiyah Magelang, Vol.14, (No 1), p.40.

Hadjon, Philipus M. (1997). Tentang Wewenang, Makalah, J urnal Yudika Universitas. Airlangga, Vol.7, (No.5\&6), p.2

Muskamal, M. (2016). Analisis Kewenangan Atribusi, Mandat dan Diskresi dalam Meningkatkan Pemerintahan yang Baik Berdasarkan Undang Undang Nomor 30 Tahun 2014 tentang
AdministrasiPemerintahan. J urnal Administrasi Publik, Vol.12,(No.2), p.125

Rokhim, A. (2013). Kewenangan Pemerintahan Dalam Konteks Negara Kesejahteraan (Welfare State), Jurnal IImiah IImu Hukum Dinamika Hukum, FH Universitas Islam Malang, Th. XIX No. 36, Edisi Pebruari-Mei 2013, p.136

Rosyadi, Muhammad. I. (2016) Wewenang Badan Pemeriksa Keuangan dan Badan Pengawasan Keuangan dan Pembangunan dalam Menilai Kerugian Keuangan Negara. Jurnal Mimbar Keadilan, Univ. 17 Agustus 1945, Januari Juni 2016, p.27.

Utomo, Tri Widodo W. (2016) Kaidah dan Praktek Pelimpahan Wewenang di Instansi Pemerintah, Jakarta: Makalah, Disampaikan pada Diskusi "Penggunaan Pemeriksa dan/atau Tenaga Ahli Yang Bekerja Untuk dan Atas Nama BPK", Jakarta.

Wiyaliyanti, Desyari Azhimy., Hananto, Untung Dwi., \& Juliani, Henny. (2016). Hubungan Kerja Badan Pemeriksa Keuangan Pusat Dengan Badan Pemeriksa Keuangan Perwakilan Provinsi Jawa Tengah Dalam Memeriksa Pengelolaan Dan Pertanggungjawaban Keuangan Di Daerah. Diponegoro Law J ournal, Vol.5, (No.3), pp.1-7. 